\title{
Mimari Tasarım Yarışması ile Koruma; Kayseri İç Kale Örneği
}

\author{
Hikmet ELDEK GÜNER*
}

Öz

Kentsel dokunun en önemli elemanlarından olan tarihi mekânlar, sahip oldukları bilinirlikleri ve cazibe noktası olma potansiyelleri nedeniyle korunmaları ve gelecek nesillere aktarılmalarının yanında kimi kent yöneticileri tarafından ekonomik getiri nesnesine çevrilmekte, kenti pazarlamanın ve markalaștırma sürecinin "yeni" yüzleri olarak yeniden değerlendirilerek, çoğu zaman özgün kullanımlarının dışında turizm sektörüne hizmet verecek şekilde yeniden işlevlendirilmektedir. Anadolu kentlerinden sanayi alt yapısı ile öne çıan Kayseri'de de kent tarihinin ve bu tarihe tanıklık etmiş kültür mirası yapıların kültürel değerleri dışında, varlıkları ve yeniden kullanımları ile kente ekonomik değer katabilecekleri fark edilmiş ve ekonomik gelişmenin sanayinin yanında kültür varlıkları aracılığıyla turizme odaklanması gündeme gelmiștir. Kentte sınırlı sayıda kalmış olan kültür mirası yapılar kendi özgün kullanımlarının dışında farklı işlevler ile yeniden kullanıma açılmıştır. Bu sürecin yaşandı̆̆ örneklerden birisi de Kayseri İç Kalesi'dir. Uzun bir koruma-uygulama süreci içerisinde yer alan Kayseri İç Kale'sinin değişimi geleneksel bir kültür mirası yapının koruma prosesinden bir parça farklı işlemiştir. Var olan bütün özgün değerleri ile gelecek kuşaklara aktarılması gereken ve bunun için çok geniş ve detaylı bir koruma projesi hazırlanması gereken İç Kale için yerel yönetimin ilk eylemi ulusal bir mimarlık yarışması açmak olmuştur. Kent merkezinde yer alan, kentin geçmişinin neredeyse bütün izlerini üzerinde taşıyan, verilecek yeni işlev ile yüksek turist potansiyeline ev sahipliği yapması beklenen İç Kale yarışmaya açılarak, yeniden işlevlendirilmek istenmiștir. Ancak bu durumun sonunda İç Kale koruma ile yeni yapı inșa etme arakesitinde sıkıșıp kalmıștır. Bu makale turizm bağlamında, tarihi yapıların ve geleneksel kent dokularını nasıl dönüștürüldüğünü, yarışma ile bir kültür mirası yapının nasıl etkilediğini, koruma kuramı içerisinde bu sürecin nerede yer aldığını ve sonuçların neler olduğunu Kayseri İç Kalesi üzerinden irdelemeyi hedeflemektedir.

Anahtar Kelimeler: Koruma, Turizm, Mimari yarışma, Kayseri, İç Kale

\section{Conservation with Architectural Competition; Case Kayseri Inner Citadel, Turkey}

\section{Abstract}

Historical places, which are one of the most important elements of the urban structure, are being reused as economic objects because of their recognition and potential points of attraction and they are defined as "new" faces of city to marketing and branding process. They are often used as a new building that serve the tourism sector beyond its original uses. Kayseri, which stands out with its industrial development from the other

\author{
Özgün Araştırma Makalesi (Original Research Article) \\ Geliş/Received: 06.07.2018 \\ Kabul/Accepted: 07.02.2021 \\ DOI: https://dx.doi.org/10.17336/igusbd.434510
}

${ }^{*}$ Doç. Dr., İzmir Demokrasi Üniversitesi, Mimarlık Fakültesi, İzmir, Türkiye,

E-posta: hikmeteldek@gmail.com ORCID https://orcid.org/0000-0002-3284-9928 
Anatolian cities, started to understand of the historical places potential in recent time. Thus they decided to change their economic expectation from industry to cultural tourism because of its income marge. And they started to refunctioned the limited number of historical monuments in the city. One of the example is Kayseri Inner Castle which that process is occurred. Outside of the traditional conservation approach, the conversion of Kayseri Inner Castle started with a national architectural competition. The Inner Castle, which is located in the city center and is bearing almost all the traces of the city's past and is host a very high tourist potential, was opened to national architectural competition and wanted to be refunctioned. But today Castle is trapped in the interface between protection and new building. In the context of tourism and tourism events, this article aims to examine how the competition process affected this conservation transformation, how this process took place in the conservation theory, and what the consequences were for the Kayseri Inner Castle.

Keywords: Conservation, Tourism, Architectural competition, Kayseri, Inner Citadel

\section{Giriş}

Adorno tarafından ilk kullanılmaya başlanan ve sanatsal, kültürel değerlerin birer ekonomik getiri olarak yorumlanabileceği/kullanılabileceği savını ortaya koyan "Kültür Endüstri" ${ }^{1}$ terimi günümüzde birçok alan için kullanılmaktadır. Kentlerde var olan kültür mirası yapıların kent yöneticileri tarafından sadece var olan değerlerinin (kültürel, tarihi, sanat, estetik, bellek, vb) dışında birer ekonomik değer olarak görülmesi ve kültür endüstrisine dâhil edilmesi son dönemde sıklıkla yaşanan bir uygulamadır (Başdoğan, 2017, 483-500). Koruma özellikle de kentsel koruma toplumun iç dinamikleri ile gelişmeyen, dışarıdan birileri (kent yöneticisi, tasarımcı vb) tarafından kurgulanan ve uygulanan bir olgudur. Kullanıcı çoğunlukla içinde bulunduğu yapının veya alanın değerlerinin farkında olmayarak veya kısmen farkında olarak o yapıyı veya alanı kullanmaya devam eder, öncelik var olan değerlerin korunması değil, konfor koşullarının iyi olmasıdır. Yerel yönetimler ise, mevcut kültür mirasını görünür kılmaya, restore etmeye, yeniden işlevlendirme yoluyla sergilemeye, pazarlanır hale getirmeye ve kültür endüstrisine dâhil etmeye çalışmaktadırlar. Ancak yakın geçmişte yürütülen bu çalışmalar kent kimliklerinin belirleyici bir parçası olan, bütün özgün değerleri ile koruması gereken yapıları, kültür endüstrisi için kullanılan birer tüketim nesnesine dönüştürmeye başlamıştır. Birçok kentte yaşanan süreç korumanın ötesinde kullanımın odağında ilerlemekte ve kendini farklı gösterim biçimleri ile ortaya koymaktadır. Türkiye'nin merkezinde yer alan geçmiși ticarete dayanan, günümüzde ise sanayi kenti olan Kayseri de yüzünü turizme ve kültür endüstrisine çevirmiştir. Bu bağlamda Kayseri'nin sanayi kenti özelliğinin yanına turizm kenti kimliğini de ekleme çabası, yerel yönetimin kültür yapıları ile kenti cazip kılacak yatırımlar yapmasına neden olmuştur.

Bu çalışmanın temel amacı korunması gereken çok önemli bir kültür mirası olan Kayseri İç Kalesi'nin yarışma ile başlayan koruma ve uygulama sürecini tanımlamak, İç Kale'nin somut ve somut olmayan değerlerinin ne kadar korunduğunu tartışmak ve bu sürecin sonucunda ortaya çıkan uygulamanın korunmuşluk durumunu incelemektir.

\footnotetext{
${ }^{1}$ Adorno, T. (2009b). Kültür endüstrisi (Çev. N. Ülner \& M. Tüzel \& E. Gen). İstanbul: İletişim Yayınları.
} 


\section{Kentlerin Markalaşması}

Kentlerin ekonomik odak haline gelmeleri, nesne üretiminin yerini kapital üretiminin alması, sanayileşme sürecinin sonuna gelen kentlerin turizm merkezli yatırımlar yapmaya başlamalarına neden olmuștur (Ylldız ve Alaeddinoğlu, 2007, 845863). Kentlerin sahip oldukları somut ve somut-olmayan değerlerin ekonomik sisteme, turizm endüstrisine ve halkın kullanımına yeniden nasıl dahil edileceği ya da pazarlama aracı olarak nasıl kullanılacağı yerel yönetimlerce vizyon programlarında sıklıkla yer verilen, üzerine düşünülen gündem konularının başında gelmektedir (Yılmaz Bakır, 2013, 74-82). Değer üretiminin ve bu üretim sürecinin her aşamasından ekonomik kazanç sağlamayı hedefleyen "yeni" dünya düzenine ve onun dönüșen değerler sistemine adapte olmaya çalışan kentler de, kendilerini var eden kapitalist üretim süreçlerinin ötesinde oluşan bu yeni sermaye birikim süreçlerinden pay almaya çalışmaktadırlar. Bu süreçte izleyebilecekleri yöntemler yeni bir alan keşfetmek veya var olanı cazip hale getirmek biçimindedir (Ashworth, 2011, 1-15). Küresel ekonomiye entegre olmaya çalışan Türkiye'de de bu bağlamda birçok yerel pazarlama çalışması yürütülmüş, kentlerin ilk olarak ulusal sınırlar içerisinde markalaşmaya, sonrasında ise dünya sıralamasında yerlerini üst seviyelere taşıyacak çalışmalara giriștikleri görülmektedir (Yılmaz Bakır, 2012, 16-20).

Kentler yerel değerleri ile marka olmaya çalışmakta ancak farklılıklarını da benzer yöntem ve stratejiler ile göstermektedirler. Bu yöntemlerden en çok kullanılanı ve etkili olanı da turizmdir. Turizm, 1960'lardan beri kentlerin var olan değerleri üzerinden getiri sağlayabildiği, kolay ve etkili yöntemlerin başında gelmektedir. Doğal, kültürel, sosyal, toplumsal, kentsel, mekânsal zenginliklerin korunarak, birer çekim noktasına dönüşmesi, merak edilmesi ve insanlar tarafından belirli bir bedel karşıllğında ziyaret edilmesi ve kullanılması turizmin en pozitif yönü olarak değerlendirilebilir. Ancak var olan bu değerlerin izleyiciye açılması, izleyici için yeni olanakların (daha lüks oteller, yeni alan ile ilgisi olmayan aktiviteler, vb.) yaratılmasını da gerekli kılmaya başlamıştır. Günümüzde kentler sadece var olan değerleri ile yetinmeyerek, yeni değerler üretmeye, turizm için dönüşmeye, gerektiğinde yeniden inşa edilerek birer cazibe merkezi, turistik varış noktası olmaya çalışmaktadırlar. Özellikle tarihi kentler turistleri kendilerine çekme, var olan değerlerini, potansiyellerini görünür kılarak ekonomik bakımdan gelire dönüștürme gayretiyle "ilan edilen veya sonradan oluşturulan" yeni kimliklerini "geleneksel ama yeni" ile öne çıkarma yarışına girmişlerdir. Böylece kentsel yapının en önemli kurucu elemanlarından olan tarihi mekânlar, sahip oldukları bilinirlikleri ve cazibe noktası olma potansiyelleri nedeniyle, kente turist çekme bağlamında, ekonomik getiri nesnesine çevrilmektedir. Kenti pazarlamanın ve markalaştırma sürecinin "yeni" yüzleri olarak yeniden değerlendirilerek, çoğu zaman özgün kullanımlarının dışında kültür endüstrisine ve turizm sektörüne hizmet verecek şekilde yeniden işlevlendirilmektedir. Bu çalışmalar turizmin yıkıcı yüzünü görmeden kente yeni gelir sağlamak, turisti çekmek için yapılmakta. Turizmin getirisi kadar götürüsünün de olacağı hesap etmeden çalışmalar devam etmekte.

Anadolu'da 2000'lerde hızlanmaya başlayan geleneksel yapıların kültür yapılarına dönüşme süreci, Dünya ölçeğinde bakıldığında 20. yüzyıl sonlarında birçok ülkede görülmektedir (Atagök, 2010, 55-59). Var olan ancak özgün işlevine devam edemeyen yapıların yeni işlevleri ile farklı yapılara dönüşmeleri, atıl durumdaki yapıların ekonomik bir değer olarak kapitalist sermaye dolaşım sürecine yeniden dâhil edilmelerine ulusal ve uluslararası ölçekte sıklıkla rastlanmaktadır (Urry, 1999, 37-68).

Cumhuriyetin ilanından itibaren Türkiye'nin en önemli sanayi kentlerinden biri olan Kayseri de, gelecekte turizm ile de belirli bir noktaya gelmeyi hedeflemektedir (Tekinsoy, 2011a, 171). Yüzyıllardır devam eden kentteki girişimci ruh ve sermaye 
birikim becerisi nedeniyle de Türkiye'nin önemli sanayi ve ekonomik odaklarından biri olmuştur (Eldek, 2017). Geçmişte tarihi konut ve ticaret dokusunu yok ederek yalnızca tekil anıt yapıları koruma altına alan Kayseri, sahip olduğu bu sıra dışı koruma ve planlama anlayışı nedeniyle hızlı imar hamlelerine ev sahipliği yapmıștır. İpek Yolu ticaretinden beri süregelen ve yüzyıllar içinde oluşmuş tarihsel birikimini hoyratça yok eden Kayseri, geriye kalan sınırlı sayıdaki kültürel değerini kullanarak, kültür rotaları oluşturmaya, bir dizi restorasyon projesi ile geçmişi yaşatmaya ve yeniden işlevlendirme çalışmalarına başlamıştır. Kültür varlığı bakımından oldukça değerli birikimlere sahip olan ancak bu değerlerin farkında olunmadığı için yakın bir zamana kadar yıkarak, yapıların sadece parsel değeri üzerinden yatırım yapmaya çalışan yerel yönetim bakış açısını değiştirmiş, kalan anıtsal yapıları korumaya, canlandırmaya ve kullanmaya başlamıştır. Kentte bu hedefin başarılı olduğu, kimi bölgelerde ise başarısız olduğu örnekler bulunmaktadır. Çalışma, kent tarihinde derin izlere neden olan İç Kale'nin yarışma ile başlayan yeniden işlevlendirme projesine odaklanmakla birlikte, kültür yapısına dönüştürülen savunma yapısının önemini daha iyi anlayabilmek için kent tarihinde yaşanan hızlı dönüşümlere, kent yönetiminin uygulamaya koyduğu kültür odaklı değişimlere iliş̧in kısa bir bilgilendirme yapılmasını gerekli kılmıştır. Bu çalışmanın temel amaçlarından biri korunması gereken birçok önemli bir kültür mirası olan İç Kale'nin yeni bir işleve dönüşüm sürecini ve bu süreçte kullanılan yöntemi (yarışma) ve sonrasında ortaya çıkan ürünü değerlendirmektir. Bu değerlendirme kapsamında kültür ekonomisinden, marka kentlere, sosyolojik değişimden, ekonomik getirilere, koruma ölçütlerinden, kent (Kayseri) tarihine kadar birçok konu incelerek, İç Kale'nin değerleri ortaya çıkarılarak ve değișim süreci anlatılmaya çalışılmıștır.

\section{Kayseri Kentsel Değişim Süreci}

Kayseri kenti 6000 yıllık oldukça köklü bir tarihe sahiptir (Karatepe, 2005a). Günümüze ulaşan tarihi yapı stoğu dikkate alındığında kentte zaman içerisinde ciddi değişimlerin yaşandığı görülmektedir. Kent tarihine kısaca değinmek bu değişimi nasıl olduğunu göz önüne serecektir.

Kent Orta Anadolu'nun tarih boyunca ticaret yolları üzerinde konumlanan en verimli bölgelerinden biri olan Erciyes dağ yamacında kurulmuştur. Kent merkezinde günümüze ulaşabilmiş en eski eserlerden biri Kale'dir. Kale'nin yanı sıra, günümüzde Kayseri'nin korunması gereken kültür mirasının sayısal olarak önemli bir bölümünü oluşturan Selçuklu Dönemi'ne ait yapılar da kent merkezinde yer almaktadır. Osmanlı Dönemi'nde kentin mekânsal yapısı diğer dönemlerden ayrılarak kale dışına taşarak genişlemiştir (Palamutoğlu, 198). Tarih boyunca etkin bir ticaret aksı üzerinde konumlanan kente Osmanlı Dönemi'nde hanlar ve çarşılar eklenmiştir. 18. ve 19. yüzyılda kent, surların dışına doğru hızla saçaklanarak her yönde genişlemiştir. 20. yüzyıl başında kentte imar hareketleri yoğunlaşsa da I. Dünya Savaşı'nın başlaması ile ortaya çıkan ekonomik sorunlardan dolayı çalışmalara devam edilememiştir. 1923 yılında Cumhuriyet'in ilan edilmesi ile beraber Kayseri'de de diğer kentlerde yaşanan değişimler başlamıştır (Karatepe, 2005b). 1930'lu yılların başında kent oldukça harap durumdadır, ilk planlı imar hareketleri de bu yıllarda başlatmıștır. 1950 sonrası Türkiye'nin her bölgesinde yaşanan göç hareketleri, Kayseri'yi de etkilemiştir. 1950-1960 yılları arasında geleneksel kent dokusunun önemli bir bölümü yok edilerek yeni konutlar ve iş yerleri inșa edilmiştir. 1960 yılında yapılan yeni ekonomik yatırımlar nedeniyle kent, yeni alanlara doğru yayılmaya başlamış, bu durum geleneksel dokuda tahribatların devam etmesine neden olmuştur (Tekinsoy, 2011b, 38-78). 1975 yılında hazırlanan nazım imar planı ile yüksek bloklu geniş caddeli kent görünümü oluşmaya başlamıştır. 

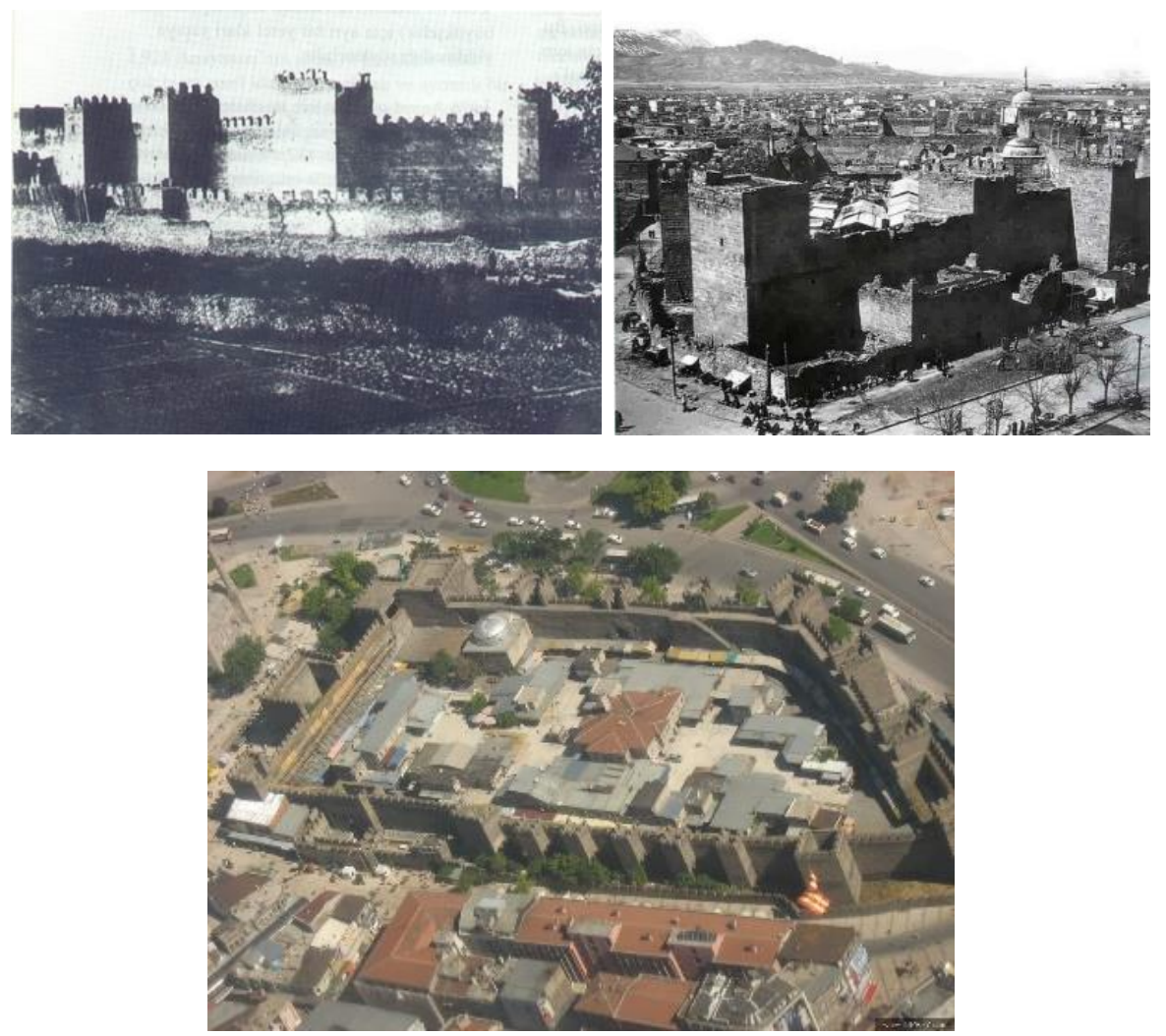

Şekil 1. Kayseri İç Kale ve Çevresinin 19.yy² ve 1950³, 20034 Yıllarındaki Görünümleri

\footnotetext{
${ }^{2}$ http://daskalosa.eu/history_st/st_istoria_en.d_5_i_thraki,__mikra_asia_kai_o_pontos,_akmaia ellinika kentra.html

${ }^{3}$ http://oldkayseri.blogspot.com/

${ }^{4}$ http://wowturkey.com/t.php?p=/tr113/Alpaslan1453 Kale Usten 1453.jpg
} 

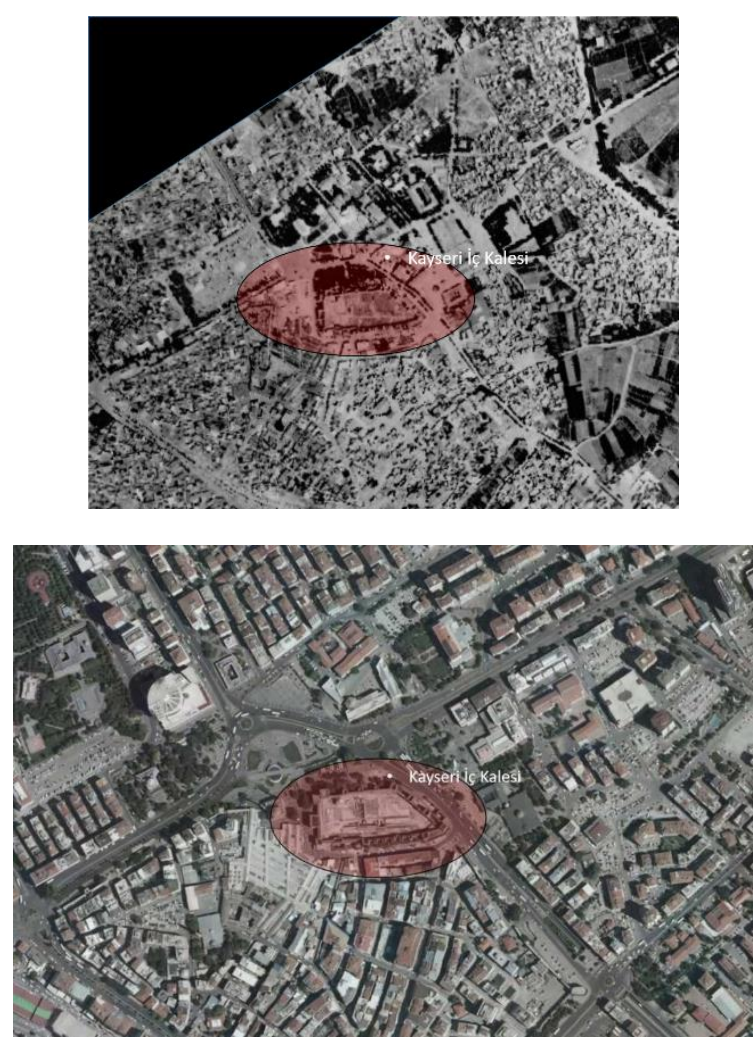

Şekil 2. Kayseri 1947 ve 2002 Hava Fotoğrafları ${ }^{5}$

2005 yılında yürürlüğe giren yeni yasa ile yerel yönetimin yetki sınırları oldukça genişlemiştir. Genişletilen bu yasal düzenlemeler ile yönetimin kültür mirası olan yapılara yönelik karar verme yetkisi artmış ve gerekçeleri belirtme koşulu ile müdahale etme hakkı da doğmuştur (Erençin, 2006, 17-29). Üretim kenti olmanın yanında kültür kenti olmak içinde çalışmalar yürüten yerel yönetim, gelecekte kentin bir marka olarak Dünya'ya tanıtılması ve değerlerinin kültür endüstrisinin bir parçası olarak pazarlanabilmesi için çalışmalarına günümüzde de devam etmektedir. Ayrıca kentsel gelişimin sadece ekonomik olmaması gerektiği gerçeğini fark eden yönetim, kültürel bağlamda, kentin tarihini, kültürünü, değerlerini ve yaşam biçimini yansıtan çalışmalar üretmeye başlamıştır. Kentlerin markalaşarak yeni bir kimlik sahibi olması gerektiği düşüncesini benimseyen belediye öncelikle kültür varlıklarına yönelik koruma çalışmaları başlatmış, elde kalan tarihi doku ve yapılar için restorasyon projeleri yürütmüştür. Merkezde yer alan tarihi yapılar için kültür rotası belirleyerek, gelen ziyaretçiler için bir güzergâh belirlemiştir. Bu güzergâhın merkezinde yer alan İç Kale'nin dönüşümü yerel yönetimin ilk girişimlerinden olması Kayseri koruma tarihi içinde önemli bir nirengi noktası olmasına neden olmuştur.

\footnotetext{
${ }^{5}$ Kayseri Büyükşehir Belediyesi Citysurf Uygulaması.
} 


\section{Kayseri İç Kalesi’nin Kültür Merkezine Dönüşüm Serüveni}

Kent tarihinin en önemli şahitlerinden biri olan Kayseri Kalesi; iç ve dış kale olmak üzere iki bölümden oluşmakta ve kent merkezinde yer almaktadır. Dış kale surlarının büyük bir kısmı tahrip edilmiş olsa da, ayakta kalan burçlar sur izlerinin kısmen okunabilmesini sağlamaktadır. İç kale ise günümüzde tamamen ayakta olup, tam bir savunma yapısı görünümündedir. Makalenin ana konusu olan İç Kale'nin ilk temelleri Roma Dönemi'nde atılmıştır (Eravşar, 1998). Bizans Dönemi'ne gelindiğinde kalenin sur duvarları genişletilerek, yeni surlar ilave edilmiştir (Akok, 1976a, 5-38). İç Kale'ye yapılan en büyük müdahaleler Selçuklu Dönemi'nde yapılmıştır (Tekinsoy, 2011c, 157-165) . Bu dönemde Moğol istilasına karşın kale güçlendirilmiş, tam bir savunma yapısına dönüştürülmüş ve kalenin bugünkü haline gelmesi sağlanmıștır. Osmanlı Dönemi'nde Anadolu merkezinde savunmaya yönelik herhangi bir durum söz konusu olmadığından, birçok kentte kale yapıları savunma amaçlı kullanımın dışında farklı işlevlerde kullanılmıştır (Çalısır Hovardaoğlu, 2009a, 87-90). Bu dönemde Kayseri İç Kalesi de savunma yapısı olmaktan çıkıp, yerleșim alanına dönüștürülmüştür. Evliya Çelebi Seyahatnamesi'nde Kale'nin halk tarafından rahatlıkla kullanıldığını ve giriş-çıkışların kolaylıkla sağlanabilmesi için kapıların genişletilerek onarıldığını ayrıca erzak ve cephane deposu olarak da işlevlendirildiğini ifade etmiștir (Çalısır Hovardaoğlu, 2009b, 87-90) tıpkı diğer pek çok Anadolu kentinde olduğu gibi. Osmanlı İmparatorluğunun son dönemlerinde ise kale boşaltılarak, bir süreliğine hapishane olarak kullanılmıștır. 1916 tarihinde İç Kale tamamen boşaltılmış, var olan inşa tarihi tam olarak bilinmeyen ancak 15. yy'a ait olduğu düşünülen Fatih Cami dışında mevcut olan yerleşim alanı tamamen yıkılmıştır.

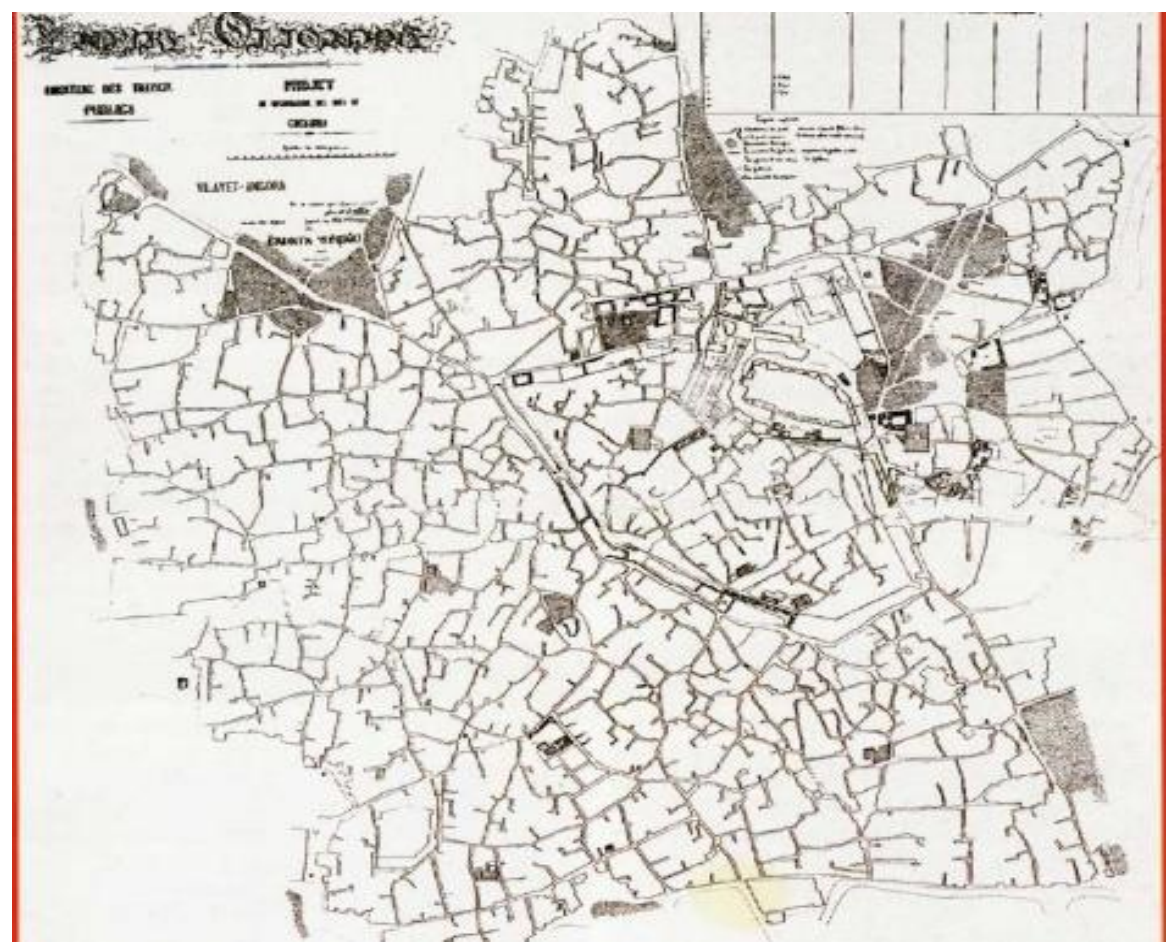




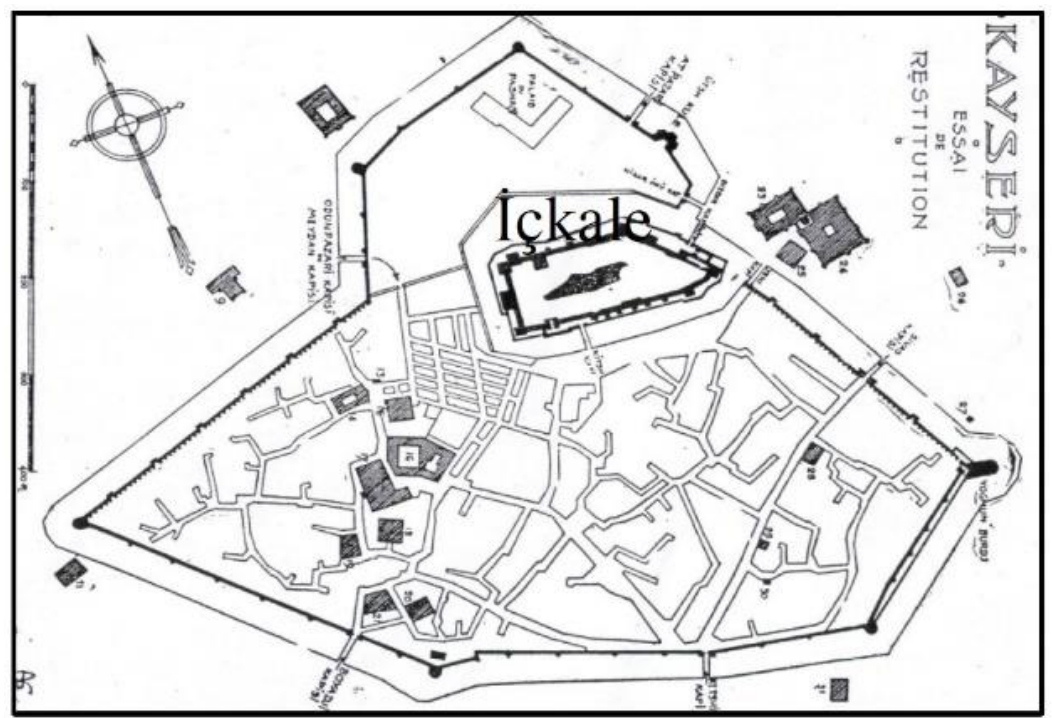

Şekil 3. Kayseri Eski Kent Planları (Eravşar, 2000, 48-54), (Gabriel, 1954)

Cumhuriyet'in ilanı ile birlikte Kayseri kent merkezinde birçok imar faaliyeti başlatılmıştır. Bu faaliyetlerden biriside İç Kale'nin Pazar yeri olarak kullanılması olmuştur. Kale uzun süre kentin alışveriş merkezi olmuştur. Yerel üreticiler ile kente dışarıdan gelen satıcıların karşılaştığı, ürünlerin satıldığı pazar alanı kentin en önemli sosyalleşme mekânı olmuştur. Halk tarafından yoğun bir biçimde kullanılan İç Kale ve çevresi 1979 yılında kentsel sit alanı olarak ilan edilmiştir (Çalısır Hovardaoğlu, 2009c, 124-128). Köklü geçmişi, korunan plan șeması ve özgün yapım malzemesi ile korunması gereken kültür mirası olan İç Kale için 1981 yılında belediye peyzaj çalışması yürütme kararı alsa da T.C. Kültür ve Turizm Bakanlığı Gayrimenkul Eski Eserler ve Anıtlar Yüksek Kurulu yapıya çarsı işlevi verilmesine karar vermiştir. 1985 yılında İç Kale için kapsamlı bir restorasyon çalışması başlatılarak, detaylı rölöveler KÜLTÜR BAKANLIĞI tarafından yürütülmüştür. Bu çalışmalar sonucunda Bakanlık çalışanı Mahmut Akok tarafından kalenin farklı dönemlere ait restitüsyon önerileri geliştirilmiştir. 

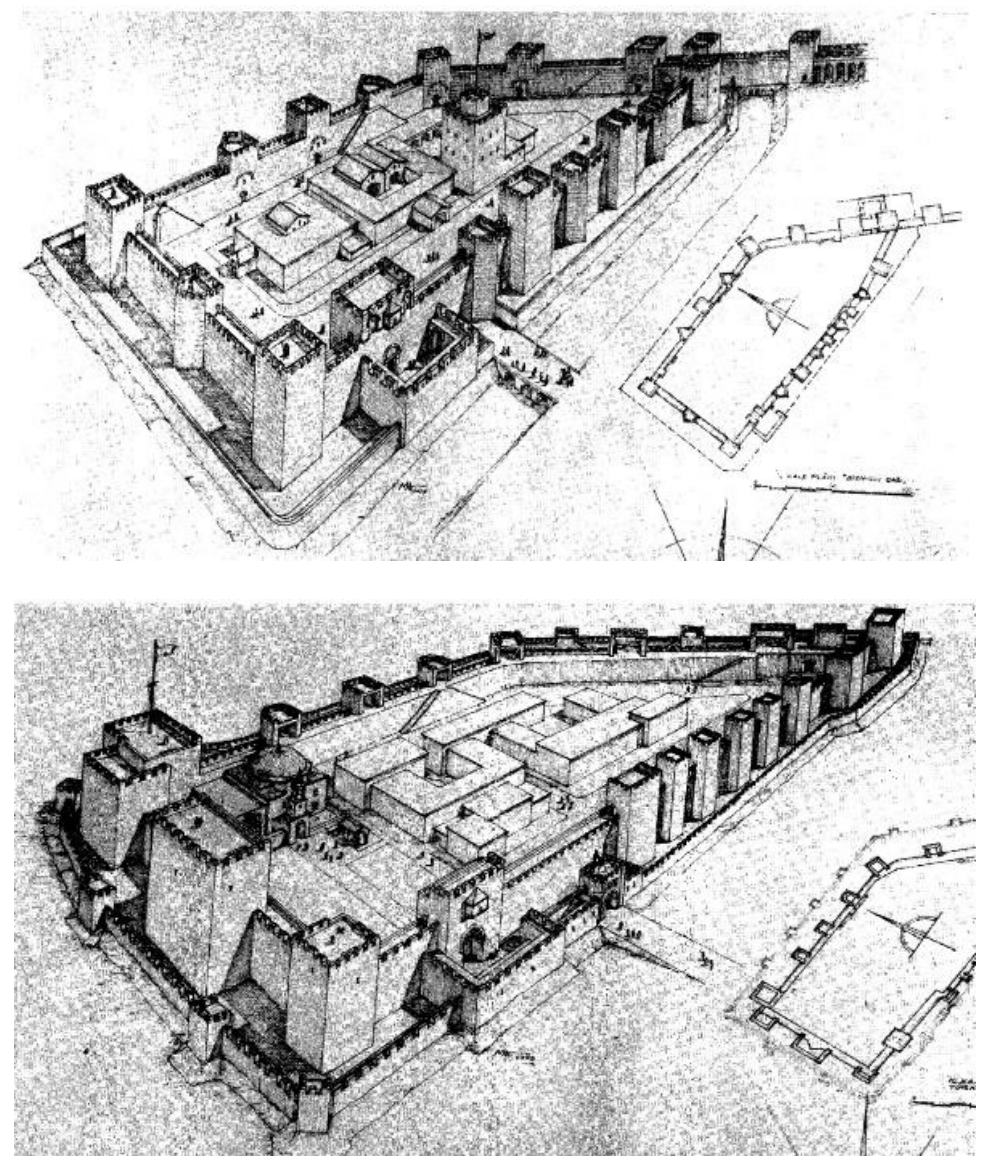

Şekil 4. İç Kale için Restitüsyon Önerileri (Akok, 1976a, 5-38.)

Ancak aynı yıl içerisinde Kayseri Koruma Kurulu üyesi Prof. Dr. Ümit Serdaroğlu tarafından İç Kale içerisine betonarme yapım tekniğinde, taş kaplamalı, Kayseri geleneksel konut dokusundan referanslar alınarak modern bir çarşı kompleksi tasarlanarak, uygulanmıştır. Kale duvarlarından 10 metre geriye çekilerek inşa edilen çarşı İç Kale'nin ortasında bir ada biçiminde uygulanmıștır. 1994 yılında dönemin belediye başkanı tarafından bu 10 metrelik boşluğa çarşısının daha yoğun kullanımının sağlanabilmesi için seyyar satıcıların yerleşmesine izin verilmiş ve sur duvarlarına dayanan derme çatma yapılar inşa edilmeye başlamıștır. Halk tarafından oldukça yoğun bir biçimde kullanılan Kale Çarşısı, Kale'nin kültür mirası olarak yeniden hatırlanması ile yeni bir kullanım için 2008 yılında "Kayseri İç Kalesi'nin Korunarak Kültür ve Sanat Ortamına Dönüştürülmesi; İki Kademeli Ulusal Mimarlık Yarışması" bașlığı ile yarışmaya açılmıştır (Tekinsoy, 2011d, 36). Yarışma kapsamında toplam $11.000 \mathrm{~m}^{2}$ alan için yeni kullanım önerilerinin geliștirilmesi hedeflenerek şartname hazırlanmıștır (Şener, 2008, 4-13). Ocak (2008) ayında duyuruya çıkan yarışmanın ilk etabı için teslim süresi Nisan (2008) olarak belirlenmiştir. İki kademli yapılan yarışmanın ilk kademesine 75 proje katılmıștır. Jüri üyeleri tarafından ikinci kademeye 6 projenin geçmesine karar verilmiştir. İkinci etap için süreç Nisan (2008) başlamış ve Ekim (2008) de 
tamamlanmıştır6. Jüri seçim kararında esas konu, İç Kale'nin korunması gereken bir kültür mirası olduğu ve yeni verilecek işlevin Kale'nin özgünlügünü bozmayacak biçimde olması gerekliliği olmuştur ${ }^{7}$. Ancak yarışma ile kültür mirası kabul edilen bir yapının yeniden işlev önerisine açılması, koruma kuramı bağlamında değerlendirildiği tartışmaya açık bir konudur. Yarışma sonrası jüri tarafından da bu konunun tartışmalı olduğu Serbest Mimarlar Derneği'nin yayın organı olan "Serbest Mimar" dergisinde yer alan Yuvarlak Masa isimli bölümde de belirtilmiştir (Anon, 2009, 64-80). Korunması gereken kültür mirasının öncelikle rölöve çalışmalarının tamamlanması, sonrasında elde edilen veriler doğrultusunda, literatür taraması ile birlikte yapı için koruma projesinin hazırlanması, yapının yaşamını devam ettirebilmesi için sağlıklaştırma önerilerinin geliştirilmesi ve bu koruma sürecini destekleyecek veya yapının daha kolay korunabilmesine aracılık etmesi öngörülen yeni işlev önerisinin geliştirilmesi gerekmektedir. Ancak süreç Kayseri Kalesi için ters işlemiş̦tir. Öncelik yapının kullanımı ve yeni işlevi olmuş, Kale'nin değerleri, koruma kriterleri belirlenmeden genel bilgiler doğrultusunda ulusal yarıșmaya açılmıştır. Yarıșma kapsamında yarıșmacılara kale hakkında genel bir bilgi vermesi amacıyla 1/200 ölçekli rölöve çalışmaları, kaleye ait eski fotoğraflar ve çizimler verilmiş, yarıșmacılar tarafından belirlenecek yeni işleve yönelik 1/200 ölçekli planlar, kesitler ve görünüşler beklenmiştir. Yarışmacılardan elde var olan bütün bu belgeler doğrultusunda kentin en önemli kültür miraslarından biri olan Kayseri Kale'si için hem işleve yönelik hem de kalenin korunabilmesi için öneriler geliştirmeleri de istenmiştir. Ancak belediyece verilen belgeler ile Kayseri Kalesi'nin değerinin ortaya çıkarılması ve korunması için yarışmacılar tarafından belirlenen işlev doğrultusunda, yarışma süresinde koruma projesi hazırlayabilmek oldukça meşakkatli bir süreçtir. Ayrıca böylesi az bilgi ve süre ile kent tarihinin en önemli yapısı için proje üretmek tartışmaya çok açık bir konudur.

Yarışma sonucunda ilk üçe giren projeler değerlendirildiğinde, ödül alan ekiplerin kalenin surlarını koruyarak (en az temasta bulunarak) temel işlevlerini kalenin iç boşluğuna yönlendirdikleri gözlenmiştir. İlk iki ödülde işlevler daha alt kotlarda çözülmüș, kamusal ve yeșil alan düzenlemeleri yer üstünde önerilmiştir ancak üçüncü projede Kale'nin içi tamamen doldurulmuştur. İșlev olarak bütün yarışmacılar kalenin kullanımında halkın daha etkili olması gerektiğini temel alarak kamusal mekânlar, kültür ve sanat merkezi önerisinde bulunmuşlardır.

\footnotetext{
6 http://www.mimdap.org/?p=10314a

7 http://www.tsmd.org.tr/Eklenti/16,serbest-mimar-dergisi02pdf.pdf?0\& tag1=0EF32CF8211B78DC881065B597BE2787645751E1
} 
Hikmet Eldek Güner, "Mimari Tasarım Yarıșması ile Koruma; Kayseri İç Kale Örneği”, İstanbul Gelișim Üniversitesi Sosyal Bilimler Dergisi, 8 (2), Ekim 2021, ss. 405-425.

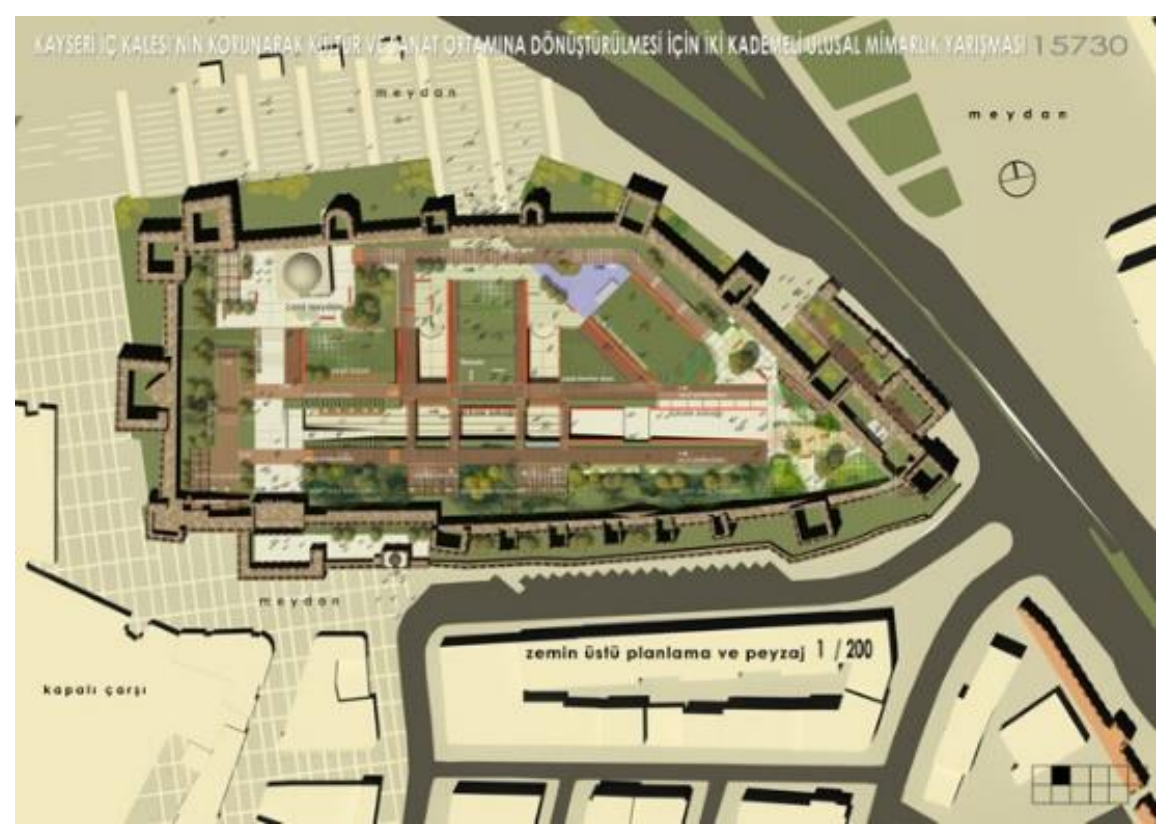

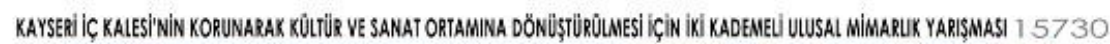

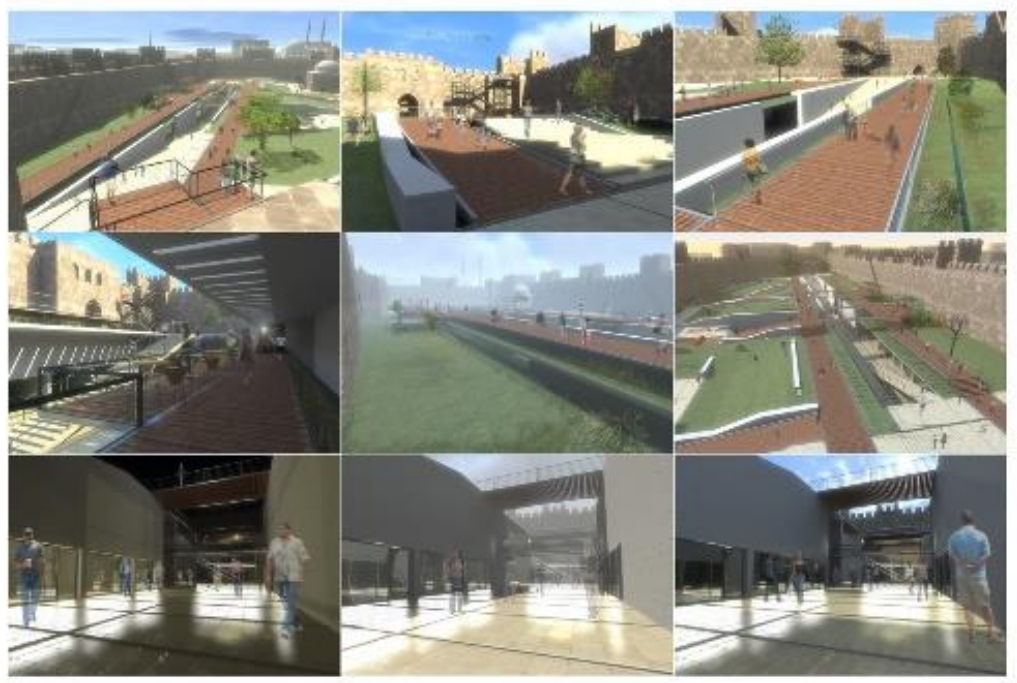

Şekil 5. Birinci Ekibin Çalışmaları ${ }^{8}$

${ }^{8}$ http://www.mimdap.org/?p=10314b 

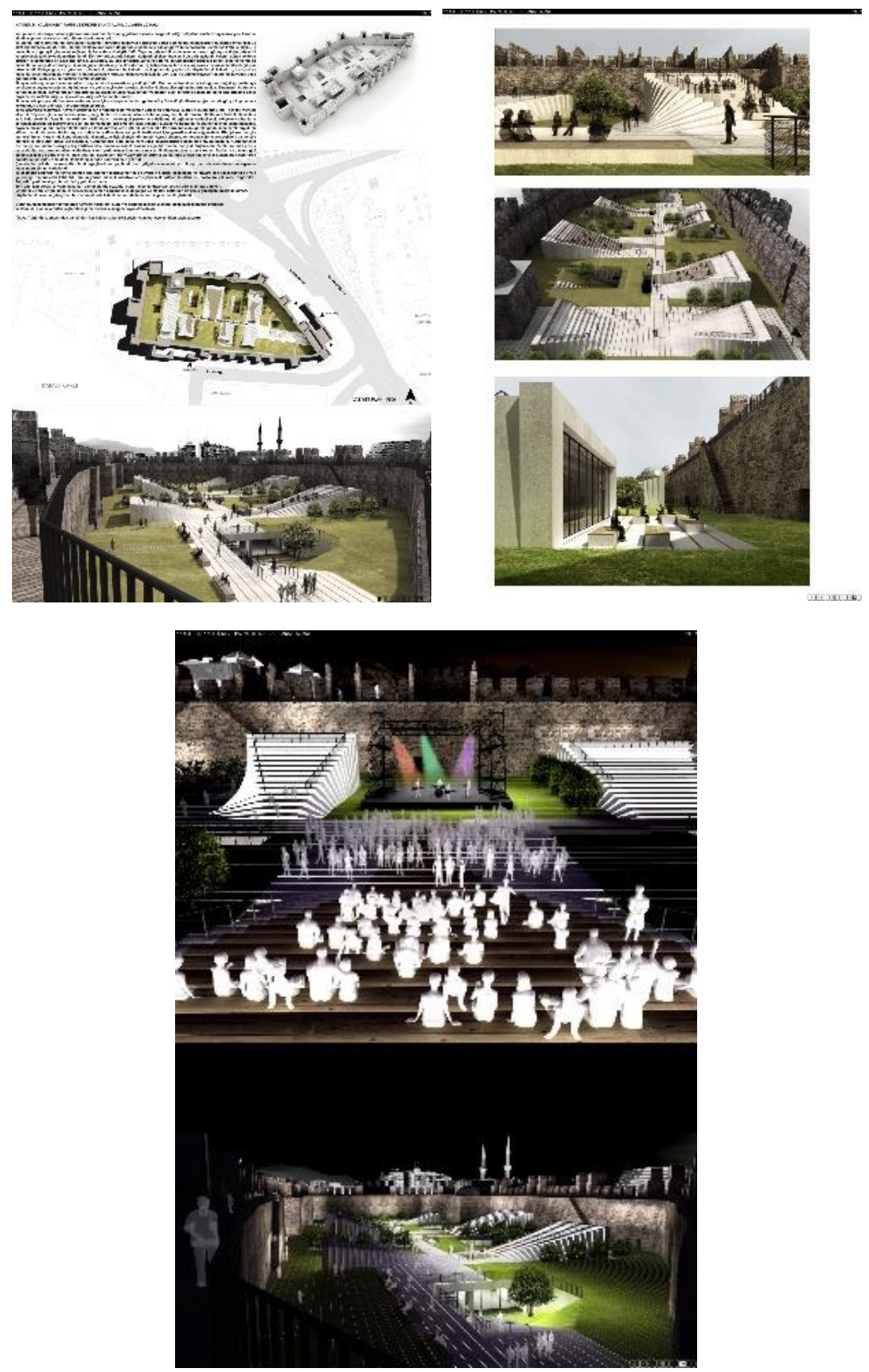

Şekil 6. İkinci Ekibin Çalışmaları ${ }^{9}$

${ }^{9}$ http://www.mimdap.org/?p=10314c 

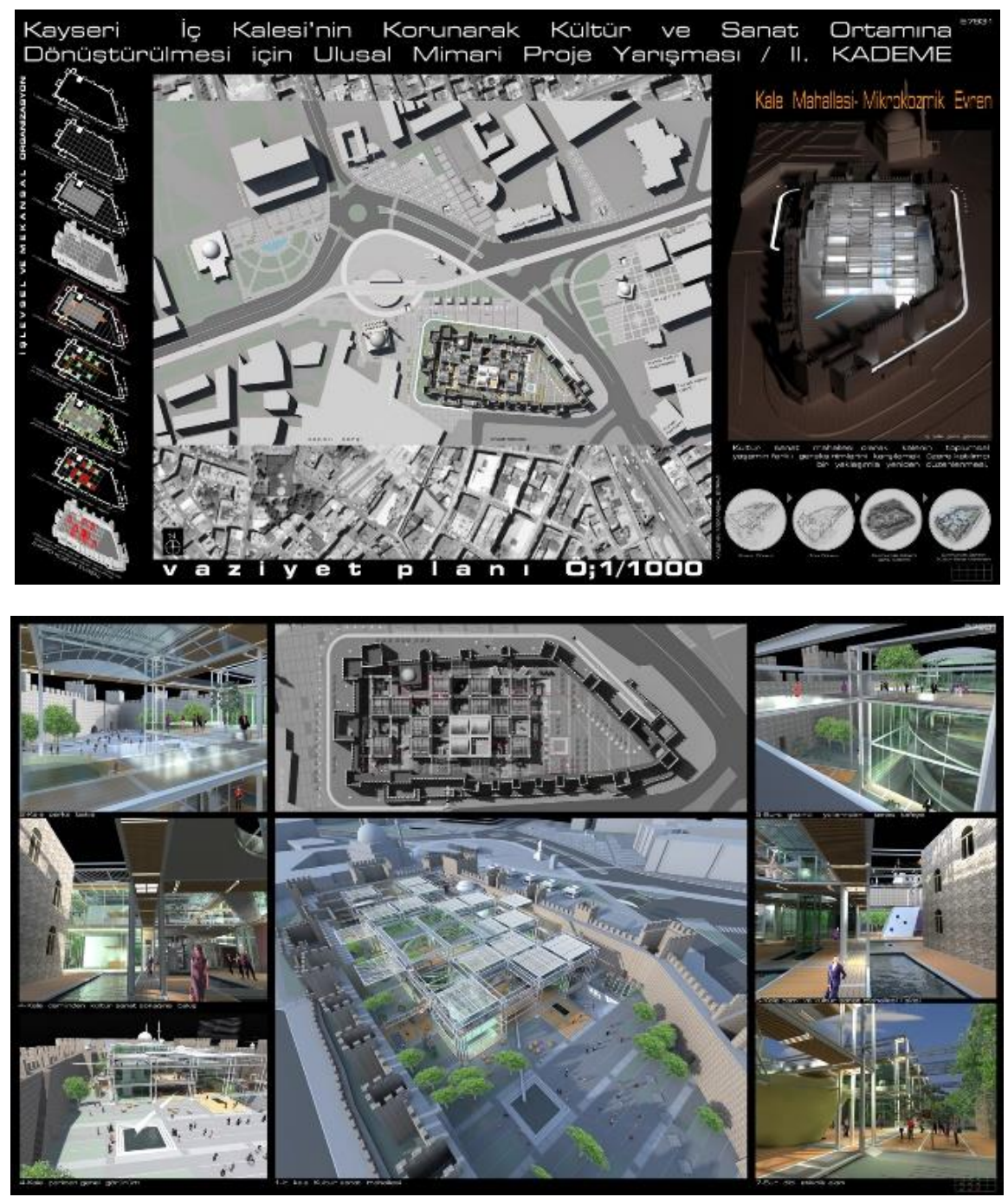

Şekil 7. Üçüncü Ekibin Çalışmaları ${ }^{10}$

Yarışma sonucunda birincilik kazanan projenin uygulanmasına karar verilmiștir. Öncelikle İç Kale'nin içerisindeki var olan dükkânlar boşaltılmaya çalıșılmıştır. Uzlaşma süreci oldukça uzun sürmüş olmasına rağmen, sonuç olarak Kale esnafı ikna edilmiş ve boşaltılmıştır. 1987 yılında inşa edilen Kale Çarşısı da uzlaşma sonrası tamamen yıkılarak, yeni yapı için alan boşaltılmıştır. Daha sonra yarışma birincilik kazanan projenin uygulamasına bazı revizyonlar ile (arkeoloji müzesi eklenmesi gibi) bașlanmıștır. 2016 yılında inşaatın tamamlanması ile hizmete açılması öngörülen kültür merkezi, kale restorasyonu gerekçesi ile açllamamıştır. İç boşluğu tamamen yenilenen, yeni yapı eklenen İç Kale için Kayseri Büyükşehir Belediyesi 2016 yılında "Büyükșehir'den Tarihi

10 http://www.mimdap.org/?p=10314d 
Restorasyon" çıkışı ile Kayseri İç Kalesi için restorasyon çalışmalarının başladığını duyurmuştur ${ }^{11}$.
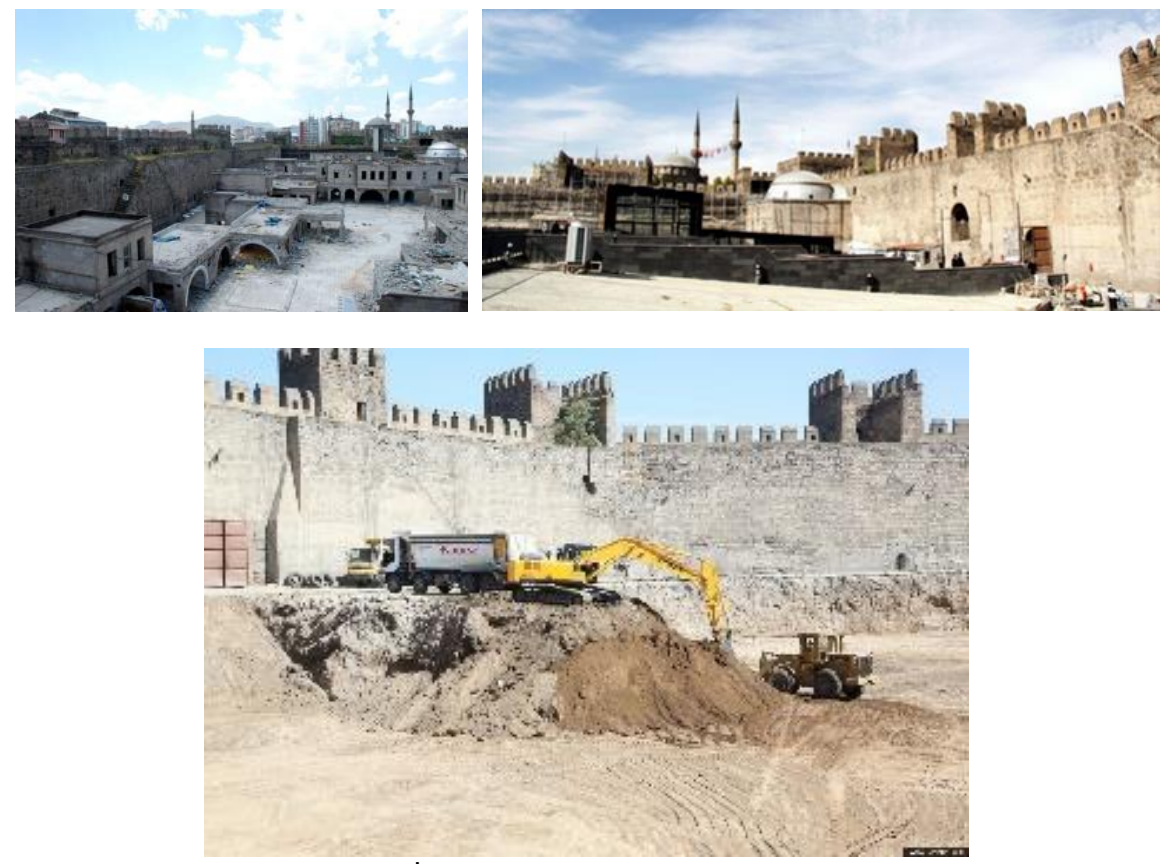

Şekil 8. İç Kale Çarşısı Yıkım Fotoğrafları12

İç Kale'nin tek önem verilmesi gereken yönünün surlar olmadığı bir gerçektir. Roma döneminde inşa edilen sonrasında birçok onarım gören kalenin iç avlusunda korunması gereken yapıların izleri öncelikle araştırılmalı ve elde edilen bulgular doğrultusunda restorasyon çalışmalarına başlanması gerekmekte idi. İnşaat süreci öncesinde böylesi bir sürecin yaşanıp, yaşanmadığı bilinmemekle birlikte, kalenin içinde yer alan çarşı hızla yıkılarak yeni yapı inşasına girişilmiş, inşa süreci tamamlanmış ve sonrasında da restorasyon çalışmalarına başlanmıștır.

\footnotetext{
11 https://www.kayseri.bel.tr/haberler/buyuksehir-den-tarihi-restorasyon

12 http://www.kayserikent.com/site/page.asp?dsy_id=54993, http://wowturkey.com/t.php?p=/tr592/Said Karahasan 2200KALE 2.jpg
} 
Hikmet Eldek Güner, "Mimari Tasarım Yarışması ile Koruma; Kayseri İç Kale Örneği”, İstanbul Gelişim Üniversitesi Sosyal Bilimler Dergisi, 8 (2), Ekim 2021, ss. 405-425.
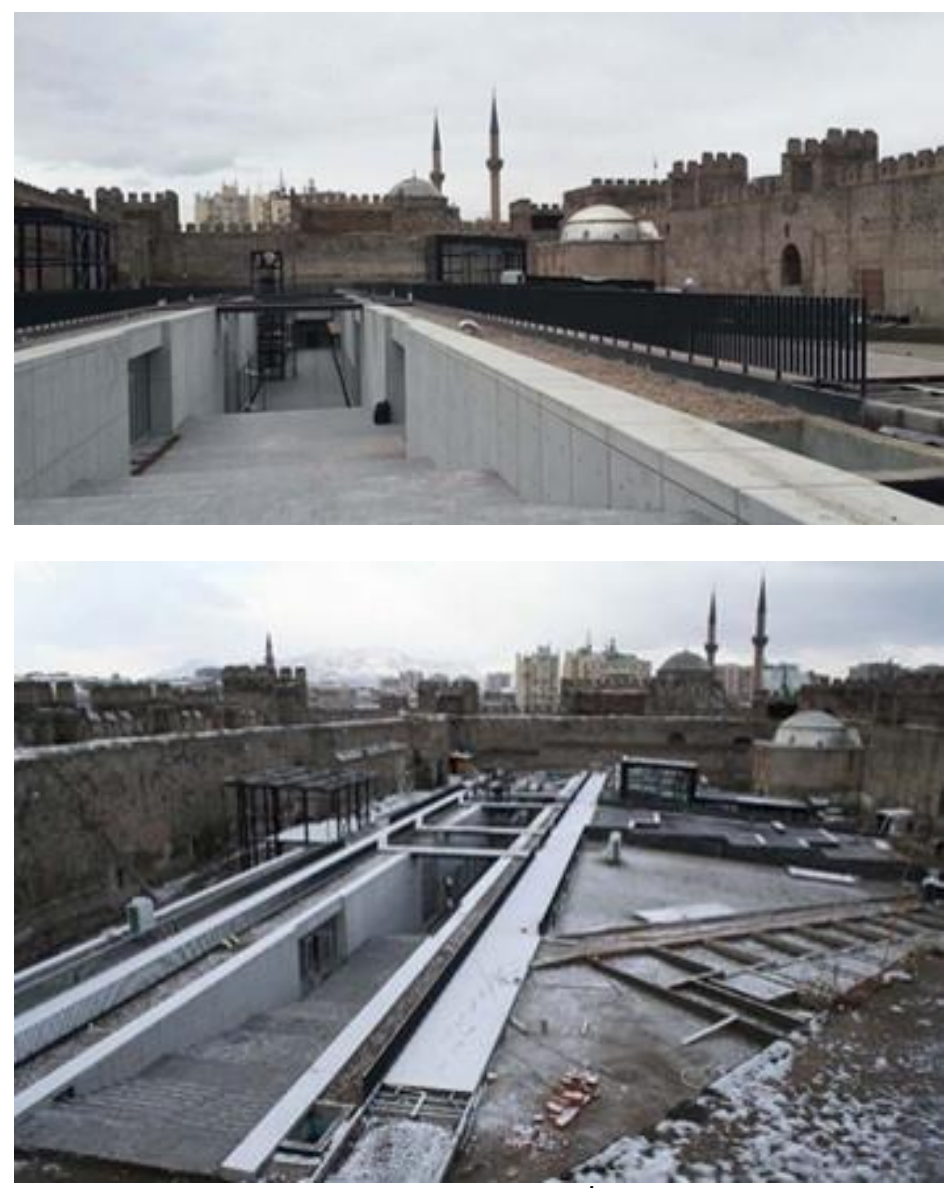

Şekil 9. Kültür Merkezi İnşası ${ }^{13}$

13 http://www.arkitera.com/haber/25895/kayseri-kaleici- 

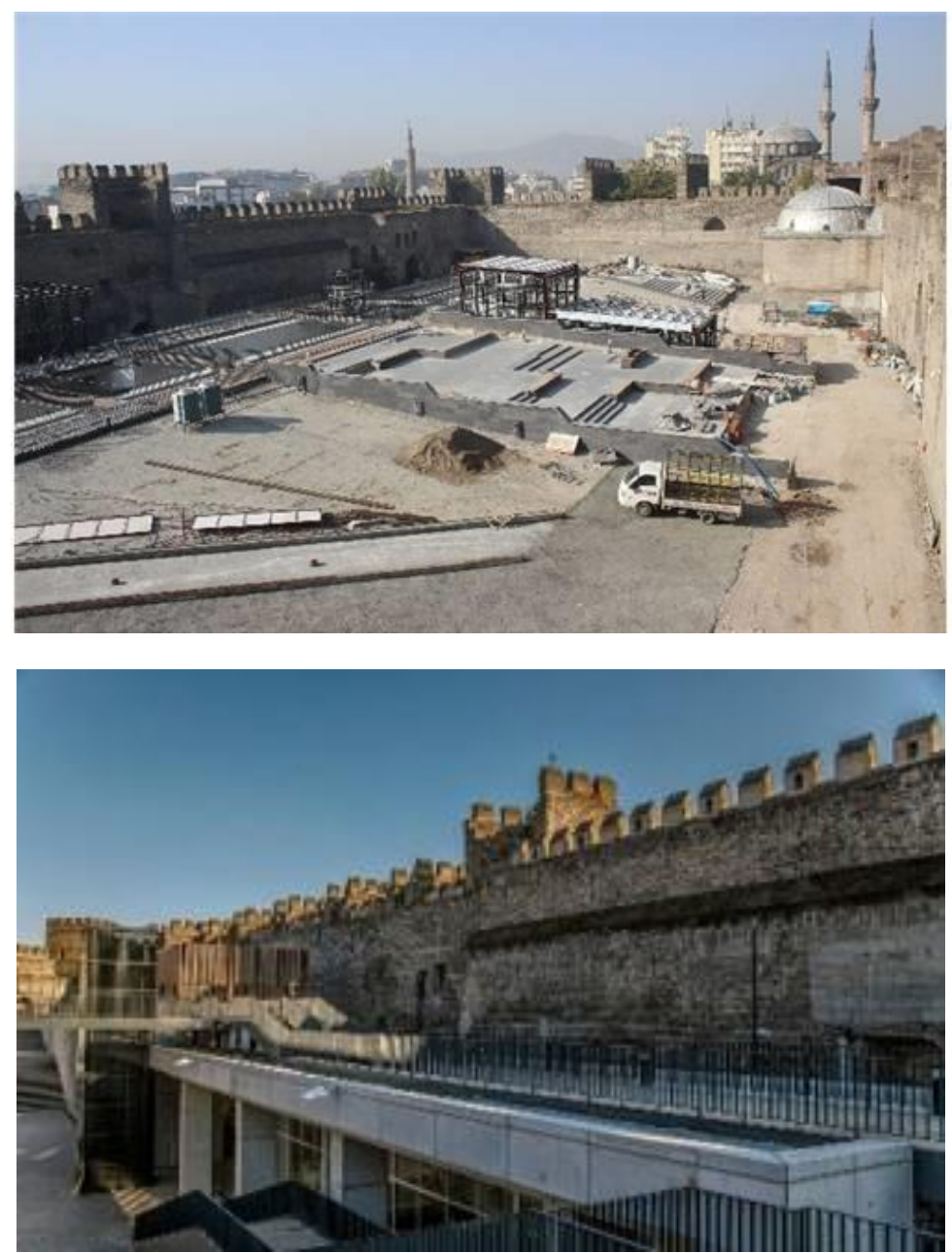

Şekil 10. Kültür Merkezi İnşası14

Günümüzde restorasyon çalışması tamamlanan ve 2019 yılında kullanıma açılmıştır. Kale içerisinde yepyeni bir yapı inşa edildikten sonra restorasyon çalışması başlatmak koruma kuramı bağlamında tartışmaya açıktır. Kültür merkezi uygulamasının korunması gereken kültür mirası olan İç Kale’ye zarar verdiği ve sonrasında onarım çalışmasının başlamış olma ihtimali bu durumda akla gelen ilk sorudur. Yarışma ile başlayan yeniden işlevlendirme süreci İç Kale'nin daha fazla zarar görmesine ve daha kapsamlı onarım geçirmesine neden olduğu da herkesin aklındaki soru işareti olacaktır.

\section{Yeniden İşlevlendirme ve Koruma}

Koruma tarihi oldukça geçmişe giden bir bilim dalıdır. İlk olarak anıtsal yapıların korunduğu daha sonra belirlenen değerler sistemi ile nasıl değere (tarihi, estetik,

${ }^{14}$ http://www.arkitera.com/haber/25895/kayseri-kaleici- 
ekonomik, politik, sosyal, vb.) sahip olduğu bakılmaksızın gelecek nesillere aktarılması gerektiği düşünülen bütün alan, yapı, obje ve somut olmayan görece kıymetli herşeyin korunması gerekliliği birçok uluslararası toplantıda dile getirilmiştir ve yazılı metin haline dönüştürülmüştür (Ahunbay, 2017). Korunması gereken kültür mirası için koruma kararı olarak onu yasal olarak güvenceye aldıktan sonraki süreç kullanımının nasıl olacağı ve bu kullanım ile mirasın değerlerinin zarar görmemesinin sağlanması gerekliliği ortaya çıkmıştır. Kültür mirasının korumasında farklı tehdit unsurları bulunmaktadır. Bunlar yaşlanma (zaman içerisinde yapıda meydana gelen eskimeler), doğal afetler (yangın, deprem vb), insan kaynaklı (vandalizm) bozulmalar olarak sınıflanabilir. Genel bozulma biçimlerinin ötesinde ekonomik kökenli bozulmalar (kültür mirasının yakın çevresinde yaşanan ekonomik çöküntü, göç, kullanıcı değişikliği vb), yönetim ve planlama kökenli bozulmalar (yönetimce alınan yanlış kararlar, uygun olmayan işlevlerin verilmesi vb) gibi daha spesifik nedenler de tarihi yapının veya çevrenin yıpranmasına hızla yok olmasına neden olmaktadır (Anonim, 209, 16-20). Koruma kuramının, tarihçesi ve oluşum nedenleri göz önüne alındığında temel hedefin korunması gereken kültür varlığını mümkün olduğunca koruyarak, var olan hiç bir değerini yitirmeden, geleceğe aktarmak olduğu görülmektedir. Korunması gereken yapıların sinıflandırılmasında, terminolojisinin belirlenmesinde ve koruma ilkelerinin ortaya çıkışında birçok kartanın ve sözleşmenin yer aldığl bilinmektedir (Anonim, 209, 16-20). Sözleşmelerden, kartalardan günümüzde de geçerliğini koruyan ve alan ölçeğinde korumanın ilk kez kullanıldığı 1964 yılında kabul edilen Venedik Tüzügü̈dür (Venedik tüzüğü, 1964). Sadece tekil yapıların değil, yakın çevresinin de bütün değerleri ile korunması gerekliliğini vurgulayan tüzügün etkileri sonrasında 1975 yılında yayınlanan Amsterdam Deklarasyonu'nda da benzer ifadeler ile devam etmiştir (Amsterdam Bildirgesi, 1975). Bütün bu belgelere bakıldığında kültür mirasına ait bütün değerlerin özellikle özgünlük değerinin ve bütüncül koruma yaklaşımının güncel koruma kuramına yön verdiği görülmektedir. 1994 yılında özgünlük değerini yeniden ele alan, somut ve somut olmayan değerleri ortaya koyan Nara Belgesi yayınlanmış, çalıșmaları daha önce bașlayan ancak 1999 yılında tamamlanan Burra Tüzüğü ile de bütünleşik korumanın altı yeniden çizilerek, koruma kriterleri ve değerler sistemi yeniden oluşturulmuş ve kültürel önemi olan mekânların yönetimi ve korunması için bir rehber hazırlanmıştır (Burra Tüzüğü, 2013). Özgünlüğün, bütüncül korumanın öneminin özellikle belirtildiği belgeler koruma ile ilgili çalışanların en temel yol göstericileridir. Bütün bu uluslararası belirleyicilerin yanında Türkiye Cumhuriyeti için de koruma tarihi azımsanmayacak bir geçmişe sahiptir. Osmanlı İmparatorluğu ile başlayan koruma süreci kültür mirası yapıların korunması için oluşturulan yasalar ve kurumlar ile devam etmiștir. Günümüz de kültür mirası için uygulanan 2863 sayılı "Kültür ve Tabiat Varlıklarını Koruma Kanunu"15 ile bir çok değerli miras korum altına alınmıștır. Ancak bu yasaların belirlediği gerekçeler veya ilkeler dışında sadece kullanım odaklı koruma yapıldığında, yapılar sadece kabuğa dönüşmekte, somut olmayan birçok değerini yitirmiş olmaktadır. İşlev korumanın en yardımcı elemanlarındandır, bilinçli kullanım korunması gereken kültür mirasının ömrünü uzatarak, gelecek nesillere aktarılması sağlar ancak bilinçsiz bir kullanım yapıyı yok eder. Tarihi yapının veya yerleşmenin tarihsel ve fiziksel özelliklerinin karmaşıklığı farklı disiplinlerin (mimarlık, koruma, kent planlama, sosyoloji, arkeoloji, ekoloji, ekonomi, hukuk, finansman, sanat-mimarlık tarihi vb) bir arada çalışmasını zorunlu kılmıştır. Uzman kișilerin bir arada koordineli biçimde gerekli zaman aralığında çalışması doğru koruma kararlarını ve sonuçlarını ortaya çıkaracaktır. Korumayı gerçekleştirecek

\footnotetext{
15 Kültür ve Tabiat Varlıklarını Koruma Kanunu, http://www.kulturvarliklari.gov.tr/Eklenti/38970,kultur-ve-doga-varliklarimiz.pdf?0
} 
uzmanların yanı sıra birçok farklı aktörde bu sürece etkin bir biçimde dâhil edilmelidir. $\mathrm{Bu}$ aktörler; kültür varlığının sahibi, yerel yönetim, halk, kullanıcı ve yüklenici olarak sıralanabilir. Bütün bu paydaşlar farklı aşamalarda kültür mirasının korunmasında etkin bir biçimde yer almakta, yapının kanuni durumunun belirlenmesinde, işlev seçiminde, uygulama kararlarının alınmasında, kullanımında söz sahibi olmaktadırlar.

Bütün bu farklı bozulma nedenlerinin, etkin paydaşların ötesinde kültür mirasının korunmasında izlenecek temel yöntem net bir biçimde belirlidir. İlk olarak detaylı belgeleme (rölöve, yapının tamamının ölçülerek, çizim ortamına detayları, yıpranmaları, bozulma tipleri ile birlikte aktarılması, analiz çalışmalarının (fiziksel, sosyal/demografik, ekonomik/finansal, arazi kullanımı/ulaşımı) yürütülmesi) çalışmasının yapılması, sonrasında restitüsyon için gerekli araştırmaların (yazılı, sözlü kaynak taraması, harita, fotoğraf gibi geçmişten gelen görsel belgelerin incelenmesi, yapı üzerinde var olan izlerin detaylıca izlenmesi gibi) gerçekleștirilmesi ve restorasyon projesinin (müdahale biçimleri, yeni işlev önerileri gibi) kültür mirasının var olan bütün değerlerini koruyacak biçimde, yapının ömrümü uzatmak amaçlı hazırlanması gerekmektedir ( Madran, 2009, 6-16). İşlev de yapının nasıl, kim tarafından kullanılmasına odaklanmadan, korunmasına odaklanarak gelecek nesillere aktarılmasına yardımcı olacak araç olarak görülerek belirlenmelidir. Bütün bunlar mimari korumanın doğru yapılması için en genel biçimde izlenecek yollardır. Her bir yapı kendi sorununu da, çözümünü de içinde barındırır, birisi için uygun olan koruma biçimi diğeri için zarar verici olabilir. 0 nedenle her yapı kendine özeldir ve kendine has yöntemler ile korunmalıdır.

\section{Sonuç}

Kültür endüstrisinin en büyük tetikleyici elemanı olan turizmin hareketlenmesi, kentlerin cazibe merkezi olmaları ve böylece marka değerlerini artırması için yürütülen çalışmaların başında kültür mirası yapıların yeniden işlevlendirilmesi gelmektedir. Kimi kentler de bu çalışmalar kültür mirasının bütün değerlerini koruyarak sağlanmaya çalışılırken, kimi kentler de tarihi yapılar sadece "yapı stoğu" olarak görülmekte ve dönüşümlerinde var olan özgün değerleri göz ardı edilerek, kullanımları ve turizm için ne kadar cazip olabilecekleri odağında çalışmalar yapılmaktadır. Kayseri İç Kalesi içinde yaşanan süreç maalesef ki kullanım odaklı olmuştur. Kayseri İç Kale'sinin yeniden işlevlendirme süreci koruma bağlamında değerlendirildiğinde oldukça radikaldir. Yakın zamanda yaşanan dönüşümün başlangıcı olan ulusal yarışma süreci, sonrasında kültür mirasının tam ortasına yapılan yeni yapı ve en son olarak da bütün inşa faaliyetlerin sonunda yapının restorasyonunun bașlaması. Kültür turizminden önemli bir pay almayı hedefleyen Kayseri, İç Kale özelinde, koruma çalışmalarının bütün süreci değerlendirildiğinde, İç Kale'nin korunmasını deneme-yanılma yöntemini kullanarak yürüttügü izlenimi ortaya çıkmaktadır. Öncelikle yerel yönetimin temel hedefi kent merkezinde kalan, kentin en tarihi yapılarından biri olan İç Kale'nin korunması değil, kentte gelen turistler tarafından kültürel değer olarak görünmesi, işlevi ile kentin modern yüzünü temsil etmesi, kale içerisinde yer alan modern kültür merkezini ve müzeyi deneyimlemesidir. Bütün bunların yapılabilmesi için yerel yönetim mimarlığın en etkin aracı olan yarışma yöntemin tercih etmiş, birçok farklı görüşü bir arada görmüş ve kendilerince en uygun projeyi seçmiştir. Yarıșma mimari proje elde etmenin en etkili ve çoğulcul yöntemidir. Birçok tasarımcı tarafından proje elde etmenin en temel ve doğru yolu olarak da görülmektedir. Ancak bir kültür mirası için yarışma düzenlemek oldukça büyük bir adımdır. Yarışma süresinin, eldeki verilerin azlığı, sonuç ürünler ile karşılaştırıldığında alınan kararların tarihi yapıya olan etkisinin ne denli büyük olduğunu ortaya çıkmaktadır. Mimari tasarımda yeni yapı elde etmek için en uygun yöntem olarak görülen yarıșma kültür mirası yapıların korunmasına geldiğinde oldukça tehlikeli ve 
korunması gereken yapıya büyük zarar verdiği Kayseri örneğinde ortaya çıkmaktadır. Kayseri İç Kale'si yarışma/koruma süreci yapıya verilen zararın net bir örneği olarak Türkiye koruma tarihine geçecektir.

\section{KAYNAKÇA}

ADORNO, T.W. (2003). Kültür Endüstrisini Yeniden Düşünürken. Cogito. Sayı: 36. (Çev. Bülent O. Doğan). Yaz, s.76-85.

ADORNO, T. (2009b). Kültür endüstrisi (Çev. N. Ülner \& M. Tüzel \& E. Gen). İstanbul: İletişim Yayınları.

Anonim, (2009). Tarihi Çevre Koruma. Dosya 14.1 Tarihi Çevrede Koruma: Yaklaşımlar. Uygulamalar Mimarlar Odası Ankara Şube Yayınları. s.16-20.

AHUNBAY, Z., 2017. Tarihi Çevre Koruma ve Restorasyon. Yapı-Endüstri Merkezi Yayınları, İstanbul.

AKOK, M. (1976). Kayseri Şehri Tarihi İç Kalesi. Türk Arkeoloji Dergisi. Sayı: XIII-

2. Türk Tarih Kurumu Basımevi. Ankara, s.5-38.

ASHWORTH, G., PAGE, S. (2011). Urban Tourism Research: Recent Progress and Current Paradoxes. Tourism Management. 32. s.1-15.

ATAGÖK T. (2010). Müzecilik ve Türk Müzeciliği. Ege Mimarlık. Temmuz. s.8-13.

DINÇER, İ. (2013). Kentleri Dönüştürürken Korumayı ve Yenilemeyi Birlikte

Düşünmek: "Tarihi Kentsel Peyzaj”, Kavramının Sunduğu Olanaklar. ICONARP.

International Journal of Architecture and Planning. Volume 1. Issue 1. pp:22-40.

ELDEK, H. (2017). Kentsel Korumanın Radikal Örneği: Kayseri.

http://www.arkitera.com/gorus/990/kentsel-korumanin-radikal-ornegi--kayseri.

Erişim tarihi: 07.06.2018

ERAVSAR, 0. (1998). Ortaçağ’da Kayseri Kent Dokusunun Gelişimi. Basılmamış

Doktora Tezi, Selçuk Üniversitesi. Konya.

ERAVSAR, O. (2000). Kayseri'de Selçuklu Kösk ve Sarayları. Çekül / Sanatsal

Mozaik Dergisi. İstanbul. 48-54.

ERENÇİN, A. (2006). Belediye Görevleri Üzerine Bir İnceleme. Çağdaş Yerel

Yönetimler Dergisi. Cilt 15. Sayı 1. Ocak. s.17-29.

GABRIEL, A. (1954). Kayseri Türk Anitları, (Çev. Ahmed Akif Tütenk), İstanbul.

KARATEPE, Ş. (2005). Kendini Kuran Kent, İstanbul, 2. Baskı, İz Yayınları.

MADRAN, E. (2009). Tarihi Çevrenin Tarihi, Osmanlıdan Günümüze Tarihi Çevre:

Tavırlar-Düzenlemeler. Dosya 14.1 Tarihi Çevrede Koruma: Yaklaşımlar. Uygulamalar

Mimarlar Odası Ankara Şube Yayınları. s.6-16.

PALAMUTOĞLU, M. (1987). Kayseri Tarihi. Kayseri, Kayseri Özel İdare

Müdürlüğü ve Kayseri Belediyesi Birliği Yayınları.

TEKINSOY, K. (2011). Kayseri'nin Imarı ve Mekânsal Gelişimi. Ankara, Kayseri

Büyükşehir Belediyesi Kültür Yayınları. Yayınları.

URRY, J. (1999). Mekânları Tüketmek. (Çev. Rahmi Öğdül), İstanbul. Ayrıntı

YILDIZ, M. Z., ALAEDDİNOĞLU, F. (2007). Küreselleşme Çağında Değișen Mekân

Algılayıșları. Türkiye, Kültürel Değişim Gelişim ve Hareketlilik 38. Icanas. Uluslararası

Asya Ve Kuzey Afrika Çalıșmaları Kongresi. Ankara, s.845-863.

YILMAZ BAKIR, N. (2013). Kentsel Proje Kavramı Ve Gelişim Süreci. Avrasya

Terim Dergisi. 1 (2): s.74-82.

YILMAZ BAKIR, N. (2012). Kentsel Planlama Ve Proje Bütünleşme Süreci Kayseri

Kenti Örneği. Basılmamış Doktora Tezi. Mimar Sinan Güzel Sanatlar Üniversitesi. Fen

Bilimler Enstitüsü. İstanbul. 
http://daskalosa.eu/history_st/st_istoria_en.d_5_i_thraki,_i_mikra_asia_kai_o_pon tos, akmaia ellinika kentra.html Erişim Tarihi: 07.06.2018.

http://oldkayseri.blogspot.com/ Erişim Tarihi: 07.06.2018.

http://wowturkey.com/t.php?p=/tr113/Alpaslan1453_Kale_Usten_1453.jpg

Erişim Tarihi: 07.06.2018

http://www.mimdap.org/?p=10314 Erişim Tarihi: 07.06.2018

https://www.kayseri.bel.tr/haberler/buyuksehir-den-tarihi-restorasyon Erişim

Tarihi: 07.06.2018.

http://www.kayserikent.com/site/page.asp?dsy id=54993 Erişim Tarihi:

07.06.2018.

http://wowturkey.com/t.php?p=/tr592/Said_Karahasan_2200KALE_2.jpg

Erişim Tarihi: 07.06.2018.

http://www.arkitera.com/haber/25895/kayseri-kaleici- Erișim Tarihi:

07.06.2018.

Venedik Tüzüğ̈;

http://www.icomos.org.tr/Dosyalar/ICOMOSTR 0612886001496825607.pdf

Erișim Tarihi: 08.06.2018.

Amsterdam Bildirgesi;

http://www.icomos.org.tr/Dosyalar/ICOMOSTR 0885391001496825356.pdf

Erişim Tarihi: 08.06.2018.

Burra Tüzügü; https://australia.icomos.org/wp-content//The-Burra-Charter-

2013-Adopted-31.10.2013.pdfuploads Erişim Tarihi: 08.06.2018.

Kültür ve Tabiat Varlıklarını Koruma Kanunu,

http://www.kulturvarliklari.gov.tr/Eklenti/38970,kultur-ve-doga-varliklarimiz.pdf?0

Erişim Tarihi: 18.01.2021.

Serbest Mimar Dergisi, http://www.tsmd.org.tr/Eklenti/16,serbest-mimardergisi-02pdf.pdf?0\& tag1=0EF32CF8211B78DC881065B597BE2787645751E1 Erişim Tarihi: 18.01.2021.

\section{Summary}

Cities use different new methods to stand out, to compete with other cities and to be able to place themselves in the new world order. Some cities are trying to bring their existing values to the forefront, while some are trying to come to the forefront with their produced urban features. All of these studies are carried out in order to set up the city's brand or to reveal existing brand values. In new world order, the branding of the city means that the city has an important place in the world culture industry. The culture industry has recently become the major source of income for cities-countries and this situation has caused them to be involved in this race. The most important element used in this race is cultural heritage buildings. Cultural heritage buildings, which are symbols of the city's histories, being expression of the preservation in the cultural context and also being an attraction points for tourist, have begun to give an importance in the last period. These buildings are renovated quickly and are often reused with different functions. These not only have being attraction points for tourists, but also have become the most effective gear of the culture industry income.

Turkey also started to be attention to many historic buildings in order to branding of the cities, so it began to reuse historic buildings with a new function. One of these cities is Kayseri, whose roots are quite old and which is one of the locomotives of the country in economic context today. Kayseri has begun to turn her face to tourism in recent years, despite being a strong industrial city. One of the most important reasons for this is to take 
profit share from the culture industry. When the city had policy to destroy cultural heritage buildings and to be built new buildings instead of them in the past, now it has been starting to preserve and reuse cultural heritage buildings by changing this point of view. Kayseri Inner Castle, one of the most historical buildings in the city, has taken its share from this change by a different approach. Conservation and restoration of cultural heritage buildings and re-functioning of them is very important process that must be done by the experts. Kayseri Inner Castle, which dates back to the Roman Period, was exposed to a rather radical protection method in terms of conservation context. Competition, which is one of the most reliable and preferred method of obtaining architecture project, was used for Kayseri Inner Castle preservation in Turkey for the first time. General information, old and nowadays photographs, 1/200 measured drawing about the Castle were given to competitors and refunctioning proposals and conservation projects were wanted from them. Projects had been prepared, awards had been determined by this limited information, which is not acceptable in the context of conservation theory. Construction of the area, which was opened for competition in 2008, was completed in 2016. However, it could not be opened for use. Starting of the restoration of the Inner Castle is stated as a reason for not being able to use.

This situation is very ironic. The castle was opened to competition in order to protect by the new function, but its conservation process has been started after new buildings construction and this caused arising of the many questions. "Has the intervention damaged the castle?" is the first question that comes to mind. There is no doubt that the answer to this question can be known by contractor, but it is unlikely that the public can learn it. So this study aims to show conservation problems of the cultural heritage buildings, which are trying to make a branding element of city and also trying to gain a significant share of the cultural industry, for Kayseri Inner Castle case. 